De Jure: Jurnal Hukum dan Syar'iah

Vol. 12, No. 2, 2020, h. 176-190

ISSN (Print): 2085-1618, ISSN (Online): 2528-1658

DOI: http://dx.doi.org/10.18860/j-fsh.v12i2.9064

Available online at http://ejournal.uin-malang.ac.id/index.php/syariah

\title{
The Actualization of Justice in the Settlement of Joint Assets Due to Divorce: Comparative Analysis of Decisions of the Religious Courts
}

\author{
JM. Muslimin \\ Universitas Islam Negeri Syarif Hidayatullah Jakarta, Indonesia \\ Jm.Muslimin@uinjkt.ac.id \\ Yulia Fatma \\ Ma'had Aly Syekh Sulaiman Arrasuli Candung Agam Sumatera Barat, Indonesia \\ yulia fatma17@mhs.uinjkt.ac.id
}

\begin{abstract}
:
The core problem examined in this paper is the practice of sharing assets in the Religious Courts. The article aims to prove that the justice provided by the judge in the distribution of joint assets is not only textually in accordance with applicable regulations, but by considering comprehensively, so that it can reflect the actuality. The urgency of this research is to emphasize that justice in the distribution of sharing assets cannot be interpreted as saying that each party must get an equal share. Justice can refer to the contributions made by both parties, both material and non-material. The used method of research focuses on a normative approach which is sharpened empirically. The normative approach requires a juridical and philosophical exploration, while empirical through the sociological approach. The results of the study conclude that the decisions of the Religious Courts regarding sharing assets are not always in accordance with the provisions of the Islamic Law Compilation (Kompilasi Hukum Islam).
\end{abstract}

Keywords: justice; join assets; judges' decision.

\section{Abstrak:}

Masalah utama yang dikaji dalam tulisan ini adalah praktik pembagian harta bersama di Peradilan Agama. Tulisan bertujuan untuk membuktikan bahwa keadilan yang diberikan oleh hakim dalam pembagian harta bersama tidak hanya semata tekstual sesuai aturan yang berlaku, akan tetapi dengan mempertimbangkan secara komprehensif, sehingga dapat mencerminkan sisi aktualitasnya. Urgensi penelitian ini untuk menegaskan bahwa keadilan dalam pembagian harta bersama, tidak bisa diartikan menjadi setiap pihak harus mendapatkan bagian yang 
sama rata. Keadilan dapat mengacu kepada kontribusi yang diberikan oleh kedua belah pihak, baik secara materi maupun non-materi. Sementara metode yang digunakan mentitikberatkan pada pendekatan normatif dan dipertajam dengan empiris. Pendekatan normatif meniscayakan uji putusan secara yuridis dan filosofis. Sedangkan empiris, melalui sisi sosiologis. Hasil penelitian menyimpulkan bahwa putusan Peradilan Agama tentang harta bersama tidak selalu sesuai dengan ketentuan Kompilasi Hukum Islam (KHI).

Kata Kunci: keadilan; harta bersama; putusan hakim.

\section{Introduction}

The problem of justice is not a new thing that happens in the Indonesian people's life. As it is known that the application of the concept of justice is sometimes responded by many parties with skepticism, especially in terms of law enforcement, because there is an assumption that justice only belongs to certain parties. This can be seen from the public discussion in handling legal cases in the country which states that there are still many court decisions considered to ignore the values of justice that should be felt by the public and justice seekers. ${ }^{1}$ The issue is too debated in the case of joint assets appearing from divorce.

The Joint assets in a marriage are assets obtained by a husband and wife during a marriage that are used to satisfy the needs of the family. In this case it does not matter who makes more money because the purpose of the income is for family welfare. ${ }^{2}$ The Joint assets in the marriage are not clearly explained by the Qur'an, Sunnah and ijtihad of the Companions of the Prophet. However, the Qur'an only mentions in the QS; al-Nisa': 32, that women and men have the same right to try and get a wage or part of their respective business. Regarding men and women in this verse cannot be interpreted as husband and wife. But the purpose of "men and women" is aimed at every man and every woman.

In Indonesia, the joint assets ${ }^{3}$ itself analogous to the term of shirkah ${ }^{4}$ which is one form of the sharing of assets in figh mu'amalah. Although the principles of cooperative institutions in ownership of assets are more on business matters, they are not much different from the rights and obligations involved in cooperative transactions over the livelihood of husband and wife in a marriage formulated by customary law. If there is a dispute in a joint asset, it can be resolved peacefully or by an agreement agreed by the parties. However, if peace cannot be made amicably and the parties have not previously entered into an agreement on a joint property, then this issue can be submitted to the Religious Courts for Muslims and the District Courts for Non-Muslims.

The submission of joint property cases to the court means the parties submit the matter to be resolved by applicable procedures. Therefore, judges as law enforcers are

\footnotetext{
${ }^{1}$ Agus Budi Susilo, "Penegakan Hukum Yang Berkeadilan Dalam Persepktif Filsafat Hermenuetika Hukum: Suatu Alternatif Solusi Terhadap Problematika Penegakan Hukum Indonesia," Perspektif XVI, no. 4 (2011): 214-26.

${ }^{2}$ Dewi Judiasih, "The Status of Matrimonial Property in Califronia and Indonesia: Community Marriage," Mimbar Hukum 27, no. 1 (2015): 145-54.

${ }^{3}$ Eric Langlais, "On Unilateral Divorce and The 'Selection of Marriages' Hypothesis," Recherches Economicques de Louvain/ Louvain Economic Review 76, no. 3 (2010): 229-56.

${ }^{4}$ Kamarusdiana and Jaenal Aripin, Perbandingan Hukum Perdata (Ciputat: UIN Jakarta Press, 2007).17
} 
obliged to decide cases properly and humanely. In giving legal considerations, a Judge is not only focused on the provisions in force, but he must also see the reality and developments and changes in society. The applicable provisions regarding joint assets are contained in Law Number 1 of 1974 concerning Marriage and The Compilation of Islamic Law (KHI). In the case of settlement of joint assets, especially the determination and distribution of it, The Marriage Law does not clearly explain the portion obtained by the parties. Unlike what is explained in the Compilation of Islamic Law (KHI), which clearly states that both have separate parts.

Seeing the reality that exists in the decisions of judges who have permanent legal force, the judge does not always give decisions related to the portion obtained by the parties equally. The judge also ruled out the applicable provisions by dividing equally. Therefore, this research will discuss related to the actualization of justice in the settlement of joint property after divorce, by analyzing several judges' decisions consisting of the decisions of the Supreme Court, the Court of Appeals and the Court of the First Instance Number 84K/AG/2018, 329K/AG/2016, 06K/AG/2015, and 33/Pdt.G/2017/PTA.JK. The selection of some of these decisions is based on cultural differences and legal provisions relating to joint property in force in Indonesia, so whether customary law influences judges' judgment in applying justice in the settlement of shared assets in court.

\section{Result and Discussion \\ The Joint Assets on Legislation}

Indonesia has rules that contain the marriage assets of a husband and wife. The purpose of marital property law is a regulation governing marital consequences related to husband and wife's assets during the marriage bond. Speaking of joint assets, normatively in Law Number 1 of 1974 concerning Marriage explains that businesses that are jointly or individually obtained during a marriage can be categorized as joint assets and become a part of the assets of the marriage without question on whose behalf. ${ }^{5}$ Besides, there are also inheritance assets in marital assets, which are the property and are fully owned by each party ${ }^{6}$

The Marriage Law does not explain in detail the provisions of the Joint assets and matters relating to them. As with accounts receivable payables related to joint assets and parts obtained by the parties. This is different from the Compilation of Islamic Law which explains in detail about shared assets and luggage. The compilation of Islamic law explains the assets in marriage in chapter XIII started from Article 85 to Article 97, where there are 13 articles discussing assets related to marriage. These articles describe in detail the assets that exist in marriage one of which is joint property. These articles explain the difference between joint assets and carry-on assets and how to obtain them and explain the relationship between joint assets and luggage in terms of categorizing assets in marriage as well as the procedures for sharing shared assets.

In contrast to the provisions regulated by Law Number 1 of 1974 concerning Marriage and KHI that separate some assets in marital property, Article 119 of the Civil Code explains that husband and wife's assets become a single entity unless there

\footnotetext{
${ }^{5}$ Ahmad Rofiq, Hukum Perdata Islam di Indonesia (Jakarta: Rajawali Pers, 2013).161

${ }^{6}$ Abdul Manaf, Aplikasi Equalitas Hak dan Kedudukan Suami Istri dalam Penjaminan Harta Bersama pada Putusan Mahkamah Agung (Bandung: Mandar Maju, 2006). 25
} 
is a marriage agreement. Husbands and wives who have entered into marriages indirectly have made the assets of both of them united with a record not otherwise determined by the agreement, both assets carried by the husband and wife and assets obtained during the marriage. ${ }^{7}$ In Article 124 of the Civil Code, it is explained that those who are entitled to take care of joint property between husband and wife are the only husband so that he has the power to manage and transfer these assets without the wife's consent. However, the wife can participate in managing joint property if there is an agreement between husband and wife (marriage agreement). ${ }^{8}$ Rules relating to joint property in the Civil Code are found in the civil law field in the marriage agreement section. ${ }^{9}$

Discussing the part obtained by the parties, the Compilation of Islamic Law is more detailed in regulating the part obtained by both the marriage breakdown caused by death or due to divorce, namely in Article 96 and Article $97 .{ }^{10}$ Both of these articles describe that marriage due to the death of a husband or wife causes half the joint property to be the right of a living partner. Then the distribution of shared property for a husband or wife whose spouse is lost must be deferred until there is the certainty of the death of an essential or legal basis based on the decision of the religious court. Besides, in marriages broken up as a result of divorce, each widow or widower is entitled to receive one-half of the joint property as long as it is not stipulated otherwise in the marriage agreement. ${ }^{11}$

Based on the description above, marriage assets that can be divided in half or by the law chosen by the parties, both positive law, customary law and Islamic law unless there are other provisions agreed upon. While the assets obtained before marriage (inherited property) and personal property (inheritance, grants, wills, and gifts) remain the property of each party. ${ }^{12}$ The husband and wife can divide up joint property during marriage according to the marriage agreement they make. If they have not previously made a marriage agreement and then there is a dispute after the termination of the marriage either due to death or divorce, then the issue of joint property can be resolved in the Religious Court.

\section{The Joint Assets on Islamic Perspective}

Islamic law does not regulate the merging of property between husband and wife during the marriage so that the assets of both of them in the perspective of Islamic law are separate. Islamic law only explains about the property of men and women and dowry when the marriage takes place. So it is possible in the marriage they have their property or personal property. The husband is not allowed to use his wife's property without her permission before. When living a household life, they may help each other in family matters because it is highly recommended. However, in principle, the maintenance of the wife and children remains an obligation of the

\footnotetext{
${ }^{7}$ Abdul Manan, Masalah Hukum Perdata Islam Di Indonesia (Jakarta: Kencana, 2008). 104

${ }^{8}$ Hilman Hadikusuma, Hukum Perkawinan Indonesia Menurut Perundangan, Hukum Adat dan Hukum Agama (Bandung: Mandar Maju, 2007).113

9 Yaswirman, Hukum Keluarga: Karakteristik Prosepk Doktrin Islam dan Adat Dalam Masyarakat Matrilineal Minangkabau (Jakarta: PT Raja Grafindo Persada, 2013).216

${ }^{10}$ Amir Syarifuddin, Hukum Perkawinan Islam di Indonesia: Antara Fikih Munakahat dan Undang-Undang Perkawinan (Jakarta: Kencana, 2006). 185

${ }^{11}$ P.N.H Simanjuntak, Hukum Perdata Indonesia (Jakarta: Prenadamedia, 2016).95

${ }^{12}$ Abdul Manan, Aneka Masalah Hukum Perdata Islam di Indonesia (Jakarta: Kencana, 2014).129
} 
husband. ${ }^{13}$ There is no discussion of joint assets in the fiqh literature because the Qur'an and Hadith specifically do not explain the institutionalization of joint assets between husband and wife. ${ }^{14}$ In the book of fiqh, it is only explained related to property or household furniture (مَتَاعُ البَيْت ), al-Sarkhasi states that household furniture is divided according to the needs of each party if the furniture is the needs of a woman or wife, it becomes the property of the wife as well as the man or husband. ${ }^{15}$ Imam Shafi'i argues if there is a dispute between husband and wife related to household furniture whether due to divorce then both parties are required to swear. If one party is unwilling to swear then the furniture belongs to the party who wishes to swear. If both of them are willing to take a swearword, the property or furniture can be divided into two, both those assets which are normally used by men or specifically for women or those that are commonly used together. ${ }^{16}$ The two opinions above are not much different from those stated by Imam Malik that disputed husband and wife related to household furniture can solve it in advance by dividing objects specifically used for men and women. But he insisted that furniture that was used together as a house then was the property of the men. But the house can become the property of the woman if she can show accurate proof of ownership of the house. ${ }^{17}$

The joint assets on mu'amalah called by shirkah between the husband and wife. In the conventional context, the family's economic burden is the result of husband's livelihood, while the wife is tasked with regulating household economic management. However, looking at the times, the wife can also do work outside the home. Two forms of involvement of both parties can be categorized as shirkah abdan (cooperation between husband and wife, capital from the husband while the wife as manager) and shirkah inan (husband and wife both have the capital and are jointly managed). In marriage, the term work is not only defined as activities outside the home, because unconsciously the wife's duty to regulate household needs is a form of work. So that in a marriage where the wife is only a housewife and husband looking for money outside the home is a form of relations between two parties. Then the results of the husband's livelihood belong to the husband and wife, and are managed jointly. ${ }^{18}$ Ismuha explains that joint property or joint search assets of husband and wife are categorized as shirkah al-abdan al-mufawadah. He Argues that in general, the husband and wife help each other to fulfill family needs. This can be seen from the situation of husband and wife who both works to support the family and invest together. Even though the work they do varies, it is seen according to the ability of each party. Common assets in Islamic law are not explicitly stated and are only explained that every person, both male, and female, has the right to their property.

\section{The Joint Assets on the Custom in Indonesia}

\footnotetext{
${ }^{13}$ Mukhtar Zamzami, Perempuan\&Keadilan dalam Hukum Kewarisan Indonesia (Jakarta: Kencana, 2013).184-185

${ }^{14}$ Mesraini, "Konsep Harta Bersama dan Implementasinya si Pengadilan Agama," Ahkam XII, no. 1 (2012): 59-70.

${ }^{15}$ Syams al-Din al-Sarkhasi, al-Mabsuth (Beirut: Dar al-Ma'rifah, 1989).213

${ }^{16}$ Muhammad Idris al-Syafi'i, al-Umm (Pakistan: Dar al-Wafa', 2001).248-250

${ }^{17}$ Imam Sahnun ibn Sa'id al-Tanukhi, al-Mudawwanah al-Kubra (Beirut: Dar al-Kitab al-'Ilmiyah, 1994).187-188

${ }^{18}$ Ahmad Rofiq, Hukum Perdata Islam di Indonesia.201
} 
In customary law, marital property is the entire property of a husband and wife as long as it is still in the bond of marriage, both those assets including the assets of relatives who are controlled, as well as their property. These assets include inheritance, grants, own income, livelihood with husband and wife and gifts obtained. Marriage assets are assets that serve to meet the needs of the lives of husband and wife and their children. ${ }^{19}$ The existence of marital property depends on the form of marriage performed, the respective customary law and the condition of the domestic peoples concerned by considering whether the custom still maintains matrilineal, patrilineal or bilateral/parental lineages, or still adheres to religious law, or has developed accordingly changing times. ${ }^{20}$

The Customary Law Institution in Indonesia categorizes several forms of marital property. In a contrario, each spouse has the same with the property of marriage which is grouped by Islamic law and BW (burgerlijk wetboek), i.e.; a) Assets obtained before marriage, in Bali those are called by guna kaya, in South Sumatra are called by harta pembujangan, and in Minangkabau are called by harta pembujang. This property is controlled by each party; b) Assets given by the family as business capital or in the form of household property, in Minangkabau those are called by harta asal. If the marriage ends, those return to the family or parents who gave it back; c) Assets obtained during the marriage, but not from their business such as grants, inheritance or will. In Central Java, East Java and Yogyakarta are called by harta gawan, in Banten are called by sulu, in Aceh are called by hareuta asal or pusaka and etc.; d) Assets obtained during a marriage that originate from the business of a husband and wife either jointly or solely are called livelihood assets. In Aceh those are called by hareuta sihareukat, in Bali are known by druwe cabro, in Java are called by harta gonogini or barang guna and etc. ${ }^{21}$ In Indonesia, there are diverse cultures and customs with a different relationship or family systems. With these differences indirectly the procedures for implementing the customs are also different, including the issue of the position of wealth in marriage.

\section{Application of Justice in Settlement of Joint Assets}

\section{The Theory of Justice According the Scholars}

The rule of law can be interpreted by realizing a sense of justice. Justice can also eliminate the impartiality of the law and make it stick to the substance of justice. The law will live in the presence of its own spirit of the law, namely justice. Law and justice are two elements that are interconnected with each other, this is called by "conditio sine qua non". 22 The rule of law has so far been identified with legal certainty, thus culturing the law. But it does not mean c losing your eyes and ears to a sense of justice that grows amid a society that develops and moves with time and space.

\footnotetext{
${ }^{19}$ Sonny Dewi Judiasih, Harta Benda Perkawinan: Kajian Terhadap Keseteraan Hak dan Kedudukan Suami dan Istri atas Kepemilikan Harta dalam Perkawinan (Bandung: PT Refika Aditama, 2015).7

${ }^{20}$ Hilman Hadikusuma, Hukum Perkawinan Indonesia Menurut Perundang, Hukum Adat dan Hukum Agma (Bandung: Mandar Maju, 2007). 114

${ }^{21}$ Moh. Idris Ramulyo, Hukum Perkawinan Islam: Suatu Analisis Dari Undang-Undang No. 1 Tahun 1974 dan Kompilasi Hukum Islam (Jakarta: Bumi Aksara, 1999).228-229

22 Tongat, Dasar-Dasar Hukum Pidana Indonesia Perspektif Pembaharuan (Malang: UMM Press, 2009).
} 
Sometimes the sense of justice grows and lives outside the law, so the law is very difficult to match. ${ }^{23}$

The purpose of the law is not only to get justice, but also legal certainty and usefulness. Ideally, the law must accommodate these three elements. However, some opinions say that the real purpose of the law is to achieve justice. ${ }^{24}$ The justice etimologically taken from "al-'adl" which means the state of one's soul which makes it straight. The philosophers do not understand justice only in terms of language and terms alone. But they also understand the nature of justice at the moral level, justice as a desirable quality and how justice is applied in ethical and social decision making. Philosophical ideas or thoughts related to justice continue to develop by the journey of human life. ${ }^{25}$

First, Aristotle Theory. Aristoteles (384-322 SM) argues that justice is doing good. In other words, justice is a primary value. The principle of justice put forward by him departs from a statement "for the same things to be treated the same and not the same are also treated unequal, proportionally". ${ }^{26} \mathrm{He}$ also argues that the justice is fairness in human action. So, justice according to Aristotle can be interpreted as equality and also something that is in line with the law (lawfulness). ${ }^{27}$ Aristotle is famous for several forms of justice which he devised, namely distributive justice, corrective justice and commutative justice. These three forms of justice have differences, both in terms of definition and placement. ${ }^{28}$ Distributive justice is a form of justice that is more willing to distribution, honorarium, wealth and other goods that can be accessed by the public. The fair distribution may be a distribution by the value of goodness, namely its value to society. ${ }^{29}$ The term corrective justice is an act of balancing something that is not equal due to injustice. Corrective justice seeks to provide restitution to the injured party to return to its original state before the actual loss occurs. In contrast to distributive justice which seeks to provide the rights and obligations of the parties proportionally indicating that the parties have entered into a contract that requires both to fulfill the rights and obligations of each party. ${ }^{30}$ Commutative justice requires everyone to respect each other's rights as individuals. This justice is the norm that regulates relations between individuals or equivalent institutions. $^{31}$

Second, John Rawls Theory. Justice concept according to John Rawls (1921-2002) is fairness, he mentioned justice in A Theory of Justice by "justice as fairness" (justice is a form of fairness). ${ }^{32} \mathrm{He}$ mentioned that if justice is considered as something that always expresses a form of equality, then indirectly formal justice requires that in the

\footnotetext{
${ }^{23}$ Sukarno Aburaera, Filsafat Hukum Teori dan Praktik (Jakarta: Kencana, 2013). 170

${ }^{24}$ Muhammad Erwin, Filsafat Hukum Refleksi Kritis Terhadap Hukum (Jakarta: PT Raja Grafindo, 2012). 218

${ }^{25}$ Jimly Asshiddiqie, Konstitusi Keadilan Sosial (Jakarta: PT Kompas Media Nusantara, 2018).53

${ }^{26}$ Herman Bakir, Filsafat Hukum: Desain dan Arsitektur Kesejarahan (Bandung: PT Refika Aditama, 2007). 182

${ }^{27}$ Mukhtar Zamzami, Perempuan\&Keadilan dalam Hukum Kewarisan Indonesia.132

${ }^{28}$ S. Waseem Ahmad and M. Ashraf Ali, "Aspect of Justice," Indian Political Science Association LXXII, no. 1 (2011): 309-15.

${ }^{29}$ Ali.

${ }^{30}$ Faizal Kurniawan, "Unsur Kerugian Dalam Unjustified Enrichment Untuk Mewujudkan Keadilan Korektif (Corrective Justice)," Yuridika 33, no. 1 (2018): 19-40.

${ }^{31}$ Surajiyo, "Keadilan Dalam Sistem Hukum Pancasila," IKRAITH-Humanira 2, no. 3 (2018): 21-29.

32 John Rawls, A Theory of Justice (England: The Belnap Press of Harvvard University, 1971).11
} 
legal order and institutions must treat all people equally regardless of their respective class levels. Formal justice can rule out significant injustice. Formal justice in legal institutions is an aspect of the rule of law that supports and guarantees legitimate expectations. One form of injustice is the failure of judges and other authorities to comply with appropriate rules or wrong interpretations in their decisions. ${ }^{33}$

According to Rawls there are two basic patterns of justice. The first pattern, namely the principle of freedom. It defines that everyone has broad freedom on the condition that they do not hurt others. The principle of freedom can be seen from the freedom of a person to express his opinion, to become an official, to have wealth and so on. The second pattern is the principle of difference, meaning that there are inequalities in social and economic status in each person can be an instrument of mutual help to help each other, officials should be open to everyone. Social and economic inequality is not fair, but if the inequality can help others then the inequality can be said to be fair. ${ }^{34}$ Achmad Ali said that the theory of justice put forward by Rawls was justice as fairness. The first procedure that was initiated by Rawls according to him was a form of freedom. Whereas the second procedure is economic and social inequality which must aim to help the whole community as well as the authorities and high officials must be transparent with everyone. Ali also explained that the theory of Rawls is a theory that answers the criticisms given to the flow of utilitarianism. ${ }^{35}$

Third, Majid Khadduri Theory. Majid Khadduri put forward several forms of justice in Islam, including justice in the law. According to Khadduri, justice is a legal term, but now the meaning of justice has been expanded not only in the legal aspect. According to him, law and justice can be categorized equally because some elements of justice may be contained in the substance of law, but the law may have or not have justice as an objective, depending on the purpose of the law itself. It could be the purpose of the law for justice and can be for other purposes. In Islam, law (shari'a) has a close relationship with religion, so law and religion are the will of God and have fulfilled the category of justice. But the purpose of religion is to define and determine the goals of justice and others, while the function of the shari'a is to indicate the path based on the justice of God and other realized goals. ${ }^{36}$

Basically, there are two aspects to justice, namely substantive justice, and procedural justice. Substantive justice is an internal aspect of law, the elements contained in law are representations of "truths" and "mistakes". These two vocabularies are often known as halal and haram which form several generals and special rules in Islamic sharia (Islamic Corpus Juris). Therefore, every act that must be considered fair, while the act that is forbidden is an act of wrongdoing. According to Fuqaha, an act can be categorized into fair and unjust, namely by looking at the final goals of shari'a (maqa>s\}id shari'ah), whether it meets the principle of general good (al-khair al-'a $>m$ ) ${ }^{37}$ It can be concluded that in substantive justice the thing that must be seen is the benefit of the people (public interest), with the sense that justice is realized if the public interest as an objective is determined shari'a is fulfilled.

\footnotetext{
${ }^{33}$ Rawls.

${ }^{34}$ Rawls.

${ }^{35}$ Achmad Ali, Menguak Tabir Hukum (Jakarta: Kencana, 2017).66

${ }^{36}$ Majid Khadduri, Mafhum al-Adl fii al-Islam (Suriah: Dar al-Hashad lil al-Nashr wa al-Tauzi', 1998). 161

${ }^{37}$ Khadduri.
} 
The procedural justice is an external aspect of shari'a. Procedural justice can be realized if substantive justice has been achieved. This aspect of justice, commonly referred to as formal justice, is realized at the level of equitability, accuracy and neutrality in the application of shari'a. Although in law, the elements of justice are not always obtained, one can get satisfaction if the law is applied properly and not impartial without discrimination. The judge is a representative of the Imam and the government that carries out legal and justice processes in court. Therefore the judge must have religious and legal knowledge. The judge is someone whose security is seen as an objective proof (al-Bayyinah) and the judge must have a fair character. Justice must be demonstrated by the judge during the process of giving testimony. ${ }^{38}$ Substantive justice with procedural justice has a close relationship. Procedural justice cannot be carried out if substantive justice has not been achieved.

\section{Justice in Decisions that Divide Based on the Principle of Equity Part}

This study discusses several decisions regarding the settlement of joint assets, including those that divide joint assets equally between ex-husband and ex-wife. Decisions that divide equally are decisions No. 06K/AG/2015 and 329K/AG/2016. The two decisions divide the joint assets as a result of divorce by applicable regulations, that is, equally or half of each party. From the judges' consideration in the two decisions, it can be concluded why the judge shared the joint assets, apart from carrying out juridical justice the judge also saw how things should be carried out by considering moral justice (the exercise of their rights and obligations during the marriage).

From the two forms of the decision above, it can be seen that there was no satisfaction of the parties with the decision of the judge in the first instance court so that legal efforts were submitted to the Supreme Court. The parties consider that the decision has not provided certainty, fairness, and expediency so that legal efforts are made. The three elements (certainty, fairness, and expediency) are very urgent in achieving the law. If the three elements have not been fulfilled, the judge's decision (putusan) or decision (penetapan) does not fulfill the sense of justice. After the two decisions are studied and analyzed, it can be concluded that the judge has made maximum legal efforts. This can be proven that the judge in deciding the case study and consider the actual legal events, by disclosing the evidence to obtain recognition from each party. In this case, the panel of judges not only prioritizes the interests of one party by setting arbitrary laws, but the panel of judges still relies on the existing provisions.

As contained in the Law and other provisions that the settlement of joint property can be completed by the law of each party, both positive law, Islamic law and customary law. In this case, because it was submitted to the religious court, the settlement was by the judge's decision with the applicable procedure. After studying the considerations and decisions of the previous panel of judges, it can be concluded that the judge has decided the case for this case by existing provisions without harming any of the parties. This can be seen from the legal considerations and legal sources that are used as a legal basis. Therefore, this judge's decision has fulfilled the

\footnotetext{
${ }^{38}$ Khadduri.
} 
legal certainty ${ }^{39}$ by carrying out the settlement of joint property cases by existing provisions as contained in Article 37 of the Marriage Law.

The judge in deciding the case of joint property related to the distribution of shared assets in Islamic law analogizes the partnership or shirkah between husband and wife. Collaboration conducted by husband and wife is in the form of partnership or shirkah 'abdan and shirkah mufawaddah. Although the wife does not work outside the home and only does domestic work, the wife is entitled to get a share of the property together with the principles of shirkah abdan mufawadah. And vice versa with husbands who work outside the home only and make money to meet household needs, the husband is also entitled to get a share of the property. The principle of shirkah can also be formed with both parties providing capital together (husband and wife working together) and bearing the burden of going out together then categorized to shirkah abdan inan. In several decisions made by the author, the judge has carried out an analogous analysis of the assets along with the procedures of the Shirkah principle, even though they were not included directly in the judge's judgment. However, this can be seen from the judges' considerations that relate to the rights and obligations of both parties in carrying out the household ark both in meeting household needs and carrying out household tasks. As said by Sayuti Thalib that for whatever is obtained by the husband and wife both individually and together, the property is included in joint property. This happens because of an agreement made by the husband and wife indirectly caused by a marriage contract or marriage contract. As explained in the letter An-Nisā' verse 21. Therefore, although it is not mentioned by the Shirkah contract, it is already implied in the marriage contract. Because, if the marriage contract with consent and qabul has fulfilled the marriage requirements, then an indirect marriage agreement between husband and wife has occurred. ${ }^{40}$

Concerning justice, as stated by John Rawls that justice contains principles "For given the circumstances of the original position, the symmetry of everyone's relations to each other, this initial situation is fair between individuals as moral persons, that is, as rational beings with their own ends and capable, I shall assume, of a sense of justice. The original position is, one might say, the appropriate initial status aquo, and thus the fundamental agreements reached in it are fair". He also explains that the justice does not only include the moral concept of the individual but also questions the mechanism of achieving justice itself, including how the law participates in supporting these efforts. He revealed that formal justice, substantive justice, and justice in terms of legal institutions are aspects of the rule of law that support and guarantee legitimate expectations. Something can be categorized as an injustice if there is a failure of judges and other authorities to comply with the appropriate rules or interpretations in determining a decision. However, in realizing formal justice, judges must also pay attention to substantive justice. This can be seen from the development and needs of the community. ${ }^{41}$

As for the case of joint assets, the judge decided the case without ignoring the applicable provisions. The panel of judges must consider how to determine a law

\footnotetext{
${ }^{39}$ E. Femando M. Manullang, Menggapai Hukum Berkeadilan (Tinjauan Hukum Kodrat dan Antinoi Nilai) (Jakarta: Kompas, 2007).96

${ }^{40}$ Sayuti Thalib, Hukum Kekeluargaan Indonesia (Jakarta: Universitas Indonesia (UI) Press, 1986). 84

${ }^{41}$ Rawls, $A$ Theory of Justice. $50-51$
} 
related to existing legal events. In addition to prioritizing justice, judges must also maintain legal certainty. So that the purpose of the law or the benefit of the law for connoisseurs of justice can be achieved. In achieving justice, judges must be observant in the mechanism or system of achieving that justice. This can be done by considering the existing provisions, then reviewing the legal events that occur. Justice will be created if legal certainty supports the achievement of justice in the case.

Judges cannot judge a case by deciding according to the provisions in force in the final. As in the case obtained by ex-husband and ex-wife from shared assets and thinks that it is fair. However, before that the judge must depart from the situation and conditions in determining the portion obtained by the parties. The situation and conditions that judges consider are how the journey of their household life when marriage ties are still ongoing. The judge cannot immediately decide that a wife who does not work does not have the right to joint property. Indirectly, wives who do not work have participated in contributing to the formation of joint property, both those who at the beginning of marriage did not have a job or when they were married willing to leave their jobs to join their husbands. After marriage, the wife is busy and focused on taking care of the household such as caring for children, washing, cooking and taking care of her husband's needs. This is a form of a wife's contribution to the progress of the household both in terms of harmony and in terms of wealth. Therefore, the wife has the right to get the same share as the husband from the joint assets.

In Islamic law, justice can be seen by the achievement of the aim of sharia law 'which is to provide benefits for the public interest and minimize the occurrence of harm by preserving the benefit of the servant in the world and the hereafter. This is usually called the essence of mas $\} l a h\} a h{ }^{42}$ Talking about the share of joint assets obtained by ex-wives who did not work after divorce to minimize the occurrence of mudharat such as how ex-wife can meet the needs of her life if she does not have provisions. Especially during a marriage a former wife does not have a job. Therefore, the judge gives part to ex-wives who do not work (with the condition of carrying out her obligations during the marriage. Refusing to damage later is more important, by the rules of fiqh which read:

\section{Refusing damage takes precedence over attracting benefits. ${ }^{43}$

$$
\text { درئ المفاسد مقدم على جلب المصالح }
$$

Therefore, the legislators and legal experts allow the formation of laws related to the joint property to minimize the existence of harm in the form of disputes in matters of property during marriage and prioritize the benefits, peace and clarity related to the property during a marriage. In addition, the thing that is considered to be allowed to do joint property distribution during a marriage is to maintain the values of balance between men and women without harming others, especially for women as wives. As we know in a time when wives were more likely to work at home as housewives and not make money, at that time they were only busy and responsible for taking care of the household. Even so, they are entitled to get a share of the assets generated by the husband during the marriage, because they play an

\footnotetext{
${ }^{42}$ Sa'id Ramadhan Al-Buthi, Dhawabith al-Mashlahah fii al-Shari'ah al-Islamiyyah (Damaskus: Dar alFikr, 2005). 115

${ }^{43}$ Muhammad Mustafa al-Zuhaili, al-Qawaid al-Fiqhiyyah wa Tathbiqatuha fii al-Mazahib al-Arba'ah (Damaskus: Dar al-Fikr, 2006).776
} 
important role in the formation of these assets by spending their days to take care of the household for the smooth activities or activities of the husband outside the home. If they are not given rights in the joint property, then it is feared that after the divorce the wife will suffer by not having anything for the next life provision.

This article agrees with the considerations and decisions given by the judge by dividing in half or equally between the ex-husband and the wife's wife. Even though the wife does not participate in working outside the home, the wife continues to carry out her obligations inside the home. As John Rawls argues, the gap between the strong and the weak is possible, if the weak benefit and are not disadvantaged by the decisions made. If analogous to household life, the wife does not work categorized as a weak position and only the husband makes money. However, there is a negotiating position between husband and wife that shows equality, while still giving part to wives who do not work without stunting their service while in the household.

In connection with the meaning of justice mentioned in the Quran with several forms of lafãdh, both al-'adl and al-qisth. The author can conclude that the judge decided the case of joint property by the fair meaning in the word al-qisth. As stated by M. Quraish Shihab in Tafsir Al-Misbah, that al-adl and al-qisth have a different meaning. The Word al-'adl is to put everything in its place even if it does not please one party. While the word al-qisth is justice applied to two or more parties, justice that makes them all happy. Judges in this case prioritize the pleasure of both parties by seeing whether the implementation of the rights and obligations of the wife during the marriage bond so that the formation of joint property.

\section{Justice in the Decision that Divides Not Based on the Principle of Equity Part}

Decisions that divide unequally between ex-husband and ex-wife in this study are the decisions of the Court of Appeals and the Supreme Court, the decisions No. 33/Pdt.G/2017/PTA.JK and No. 84K/AG/2018. The judges' consideration of these two decisions paid more attention to the extent of the contribution made by both parties in the formation of joint assets along with the implementation of the cooperation between the two apart from material matters, but also non-material matters. The justice contained in the decision on the distribution of shared assets whether dividing half or not dividing half already fulfills gender justice. Both forms of decisions refer to both the full rights and obligations of both parties. If the rights and obligations are fulfilled, the provisions regarding the distribution of shared assets and a half share can be implemented. However, if the rights and obligations are not fulfilled, the division of half of the portion for each party is deemed not fulfilling a sense of justice. Therefore, it can be concluded that judicial justice both substantively and procedurally can be fulfilled if the rights and obligations during the marriage can take place. However, if the rights and obligations are not fulfilled properly then juridical justice cannot be implemented, the judge must-see in terms of social and moral justice by looking at the conditions at the time the marriage takes place. as is the case, the wife works hard and takes care of the household while the husband does not work and does not participate in taking care of their household. Then the exhusband is not entitled to get as much as the ex-wife's part.

This article agrees with the judge's judgment and judgment that justice is not only seen in terms of being equal to the meanings equally but how much they are in carrying out their respective responsibilities. As Aristotle proposed that justice can be assessed with obligations or services that have been done by someone and get the 
right worth, which is known as distributive justice. Likewise with justice that John Rawls raised about justice by reviewing the negotiating position. Positions that do not discriminate against other parties or injured parties. If the negotiating position does not show a balance, then there must be defensive actions against one of the parties. Judges must take affirmative action by looking at the situation and conditions as in this case. This can be done by looking at which party is weakened in running the household during the marriage bond, which continues to re-assess the rights and obligations of each party without harming anyone. These two opinions are in line with the notion of justice put forward by Islamic thinkers, namely Majid Khadduri, which states that procedural justice (by applicable provisions) cannot be realized if it does not consider substantive justice (justice by conducting legal excavations or legal ijtihad). Substantive justice can be carried out to prioritize benefit for the achievement of the purposes of shari'a (maqas id shari'ah).

Islam also explains that it is not permissible to commit wrongdoing among mankind so that we are demanded to prioritize the benefits for the public interest and minimize the occurrence of damages ${ }^{44}$ Doing justice is a form of manifestation of maqas $\}$ id shari'ah. For the shari'a objectives to be carried out properly, ${ }^{45}$ each party must pay attention to the benefit of the people and avoid damage (the essence of mas (lah (ah). The judge divided the joint property more for the ex-wife than the exhusband in this case by looking at the benefits. If the judge decides to keep dividing the assets equally between ex-husband and ex-wife, it is feared that there will be arbitrariness later on for the benefit of the community. The general public knows about the condition of the household of the parties in this case, that the husband does not work but still gets shared property equally.

According to the author, there will be fear of stunting or insignificance from husbands not to carry out their obligations as husbands to provide for their wives. They will assume that only the wife works outside the home while they are not working and without doing anything and if there is a divorce will still get the same share of the joint property. Therefore there is a party that is injured, namely the wife, then there is a wrongdoing that brings damage. This should not happen because it is not by the objectives of the shari'a. Justice referred to by the judge is fair to create equilibrium $b$ fulfilling right and obligations, eliminating excess and gaps in all spheres of life. ${ }^{46}$

\section{Conclusion}

The Judges of the Religious Court believe that something can be said to be fair if it gives happiness to those who seek it. However, justice cannot be interpreted solely subjectively but must also consider situations and conditions. The decision of the Religious Court reflects that justice is the goal and ideals of law that must be realized by law enforcers, one of which is the judge. The judge must re-explore the value of justice that should be obtained by the parties. This problem also applies to the settlement of joint assets after divorce. Justice does not only mean the same and equal share in its distribution. Justice in the settlement of joint assets can be decided

\footnotetext{
${ }^{44}$ Khadduri, Mafhum al-Adl fii al-Islam. 163

45 Jaser Auda, Maqasid al-Shari'ah as Philosophy of Islamic Law, A System Approach (London: The International Instituteof Islamic Thought, 2008).2

${ }^{46}$ Mohammad Hashim Kamali, Shari'ah Law an Introduction, Oneworld (England: Oneworld, 2008).
} 
by re-exploring the contributions made by both parties, both material and nonmaterial. The justice prescribed by the judges refers to the contribution of each party in the formation of joint assets. In other words, justice can be assessed proportionally, not just a formality.

\section{Bibilography}

Abdul Manaf. Aplikasi Equalitas Hak dan Kedudukan Suami Istri dalam Penjaminan Harta Bersama pada Putusan Mahkamah Agung. Bandung: Mandar Maju, 2006.

Abdul Manan. Aneka Masalah Hukum Perdata Islam di Indonesia. Jakarta: Kencana, 2014.

. Masalah Hukum Perdata Islam Di Indonesia. Jakarta: Kencana, 2008.

Agus Budi Susilo. "Penegakan Hukum Yang Berkeadilan Dalam Persepktif Filsafat Hermenuetika Hukum: Suatu Alternatif Solusi Terhadap Problematika Penegakan Hukum Indonesia." Perspektif XVI, no. 4 (2011): 214-26.

Ahmad Rofiq. Hukum Perdata Islam di Indonesia. Jakarta: Rajawali Pers, 2013.

Al-Buthi, Sa'id Ramadhan. Dhawabith al-Mashlahah fii al-Shari'ah al-Islamiyyah. Damaskus: Dar al-Fikr, 2005.

Ali, Achmad. Menguak Tabir Hukum. Jakarta: Kencana, 2017.

Ali, S. Waseem Ahmad and M. Ashraf. "Aspect of Justice." Indian Political Science Association LXXII, no. 1 (2011): 309-15.

Amir Syarifuddin. Hukum Perkawinan Islam di Indonesia: Antara Fikih Munakahat dan Undang-Undang Perkawinan. Jakarta: Kencana, 2006.

Aripin, Kamarusdiana and Jaenal. Perbandingan Hukum Perdata. Ciputat: UIN Jakarta Press, 2007.

Auda, Jaser. Maqasid al-Shari'ah as Philosophy of Islamic Law, A System Approach. London: The International Instituteof Islamic Thought, 2008.

Bakir, Herman. Filsafat Hukum: Desain dan Arsitektur Kesejarahan. Bandung: PT Refika Aditama, 2007.

Dewi Judiasih. "The Status of Matrimonial Property in Califronia and Indonesia: Community Marriage." Mimbar Hukum 27, no. 1 (2015): 145-54.

Eric Langlais. "On Unilateral Divorce and The 'Selection of Marriages' Hypothesis." Recherches Economicques de Louvain/ Louvain Economic Review 76, no. 3 (2010): 229-56.

Hadikusuma, Hilman. Hukum Perkawinan Indonesia Menurut Perundang, Hukum Adat dan Hukum Agma. Bandung: Mandar Maju, 2007.

—. Hukum Perkawinan Indonesia Menurut Perundangan, Hukum Adat dan Hukum Agama. Bandung: Mandar Maju, 2007.

Imam Sahnun ibn Sa'id al-Tanukhi. al-Mudawwanah al-Kubra. Beirut: Dar al-Kitab al-'Ilmiyah, 1994.

Jimly Asshiddiqie. Konstitusi Keadilan Sosial. Jakarta: PT Kompas Media Nusantara, 2018.

Kamali, Mohammad Hashim. Shari'ah Law an Introduction. Oneworld. England: Oneworld, 2008.

Khadduri, Majid. Mafhum al-Adl fii al-Islam. Suriah: Dar al-Hashad lil al-Nashr wa al-Tauzi', 1998. 
190 | De Jure: Jurnal Hukum dan Syar'iah, Vol. 12 No. 2 Tahun 2020

Kurniawan, Faizal. "Unsur Kerugian Dalam Unjustified Enrichment Untuk Mewujudkan Keadilan Korektif (Corrective Justice)." Yuridika 33, no. 1 (2018): 19-40.

Manullang, E. Femando M. Menggapai Hukum Berkeadilan (Tinjauan Hukum Kodrat dan Antinoi Nilai). Jakarta: Kompas, 2007.

Mesraini. "Konsep Harta Bersama dan Implementasinya si Pengadilan Agama." Ahkam XII, no. 1 (2012): 59-70.

Muhammad Erwin. Filsafat Hukum Refleksi Kritis Terhadap Hukum. Jakarta: PT Raja Grafindo, 2012.

Muhammad Idris al-Syafi'i. al-Umm. Pakistan: Dar al-Wafa', 2001.

Muhammad Mustafa al-Zuhaili. al-Qawaid al-Fiqhiyyah wa Tathbiqatuha fii al-Mazahib al-Arba'ah. Damaskus: Dar al-Fikr, 2006.

Mukhtar Zamzami. Perempuan\&Keadilan dalam Hukum Kewarisan Indonesia. Jakarta: Kencana, 2013.

P.N.H Simanjuntak. Hukum Perdata Indonesia. Jakarta: Prenadamedia, 2016.

Ramulyo, Moh. Idris. Hukum Perkawinan Islam: Suatu Analisis Dari Undang-Undang No. 1 Tahun 1974 dan Kompilasi Hukum Islam. Jakarta: Bumi Aksara, 1999.

Rawls, John. A Theory of Justice. England: The Belnap Press of Harvvard University, 1971.

Sonny Dewi Judiasih. Harta Benda Perkawinan: Kajian Terhadap Keseteraan Hak dan Kedudukan Suami dan Istri atas Kepemilikan Harta dalam Perkawinan. Bandung: PT Refika Aditama, 2015.

Sukarno Aburaera. Filsafat Hukum Teori dan Praktik. Jakarta: Kencana, 2013.

Surajiyo. "Keadilan Dalam Sistem Hukum Pancasila." IKRAITH-Humanira 2, no. 3 (2018): 21-29.

Syams al-Din al-Sarkhasi. al-Mabsuth. Beirut: Dar al-Ma'rifah, 1989.

Thalib, Sayuti. Hukum Kekeluargaan Indonesia. Jakarta: Universitas Indonesia (UI) Press, 1986.

Tongat. Dasar-Dasar Hukum Pidana Indonesia Perspektif Pembaharuan. Malang: UMM Press, 2009.

Yaswirman. Hukum Keluarga: Karakteristik Prosepk Doktrin Islam dan Adat Dalam Masyarakat Matrilineal Minangkabau. Jakarta: PT Raja Grafindo Persada, 2013. 